\title{
SUBLIMINAL ADVERTISING: ETHICAL AND LEGAL PROBLEMS OF EXISTENCE IN UKRAINE
}

\author{
Mariia Kyrylenko* \\ Institute of International Relations, International Law Department of Taras Shevchenko National \\ University of Kyiv, Ukraine, E-mail: marykyrylenko5@gmail.com
}

(Received: March 2021; Accepted: May 2021; Published: May 2021)

\begin{abstract}
In the present article, the issue of identification of sophisticated and problematic aspects of the regulation of subliminal advertising in the national legislation of Ukraine and perspectives for the improvement of the legal regulation of subliminal advertising is considered. It is determined that legislative and normative regulation of public relations that arise in the process of defining the concept of subliminal advertising and the problems of such legislative regulation are urgent questions in the current society. Given that subliminal advertising affects subconsciousness and manipulates human behavior, it harms not only consumers of advertising, as it misleads, disorients, has a subliminal effect, but also deprives media outlets of adequate payment for fair advertising. Besides, hidden advertising also harms society by ignoring the laws, requirements of journalistic ethics and hence - provides demoralization. That is why there is a necessity to analyze ambiguous aspects of subliminal advertising and justify the need to improve the possibilities of its legal limitations and control.
\end{abstract}

Keywords: subliminal/hidden advertising; commercial manipulations; legal regulations; product placement; consumers of advertising.

\section{Introduction}

Everywhere we are surrounded by advertising: on television, in transport, shops, restaurants, cafes, the Internet. Direct advertising causes a sharp rejection and therefore we simply do not notice it. But this does not stop manufacturers: the alternative is subliminal advertising.

The urgency of the topic of regulation of subliminal advertising is due primarily to the fact that now Ukraine is in a state of information war. During the information war, one of the participants weakens the moral and material strength of the enemy or competitor, while strengthening their own. Second, subliminal advertising is quite dangerous because it can exert unconscious influence on the consumer and force him

*Corresponding author: Mariia Kyrylenko.E-mail: marykyrylenko5@gmail.com

Copyright () 2021 The Author(s). Published by VGWU Press

This is an Open Access article distributed under the terms of the Creative Commons BY 4.0 license (Creative Commons - Attribution 4.0 International - CC BY 4.0) which permits unrestricted use, distribution, and reproduction in any medium, provided the original author and source are credited.

59 sciendo Journal of Legal Studies Volume 27 Issue 41/2021 
Kyrylenko, M., (2021)

to certain actions. Subliminal advertising may have a damaging impact on the consciousness of people, their conduct and may cause a significant misleading and unlawful of the human and commercial relations in society. Moreover, subliminal advertising can become an information weapon. Third, the issue of the very concept of subliminal advertising and its legal regulation is insufficiently regulated. So, this topic is extremely relevant today.

Thorough studies of the concept of subliminal advertising, as well as problems of its legislative regulation, have been carried out by many legal scholars. However, this question is quite complex due to the heterogeneity of the nature of the most subliminal advertising and therefore requires a deeper and more diverse study. That is why several points are to be addressed, including the meaning of the concept of "subliminal advertising" and its regulation in the legislation of Ukraine, the analysis of the ethical aspect of subliminal advertising, the clarification, and comparison of control of hidden advertising in Ukraine and other countries of the world in regard of the ways to provide improvement of the normative basis of subliminal advertising.

\section{Subliminal advertising}

2.1. The essence of subliminal advertising, its types and methods of recognition Advertising is one of the most popular phenomena in the current world, a complex social issue that affects all spheres of society and actively influences institutions and people, contributes to the formation of lifestyles, stereotypes that reflect the cultural characteristics of the population. Due to the rapid development of market relations in Ukraine, which results in competition, there is a tendency to use rather unfair aggressive advertising techniques. Despite the fact that the advertising market in Ukraine is relatively young, most people have already formed a persistent negative image of advertising, which causes considerable irritation. Today, the Ukrainian "consumer" of the advertising stream has become more competent and more legible, which has increased its demand for advertising. Recently, there has been an increase in the number of subliminal advertisements in the products on radio, television, video, audio, which are called improperly labeled. It means that such materials do not have special marks "advertising" or "advertising rights".

There is no single definition of subliminal advertising. However, following some doctrinal approaches, subliminal advertising is information about a person, product, or service, which is presented in the form of ordinary material. It includes that such material is published (or broadcasted) outside the "Advertising" section and without the label " advertising rights". Thus, readers (viewers) do not suspect that they are offered promotional material, and therefore perceive it with more confidence and fondness. But in fact, very often it is an unfair trick.

Unfortunately, national legislation still does not provide an exhaustive interpretation of subliminal advertising and its classification. That is why it is very difficult to

60 Sciendo Journal of Legal Studies Volume 27 Issue 41/2021 ISSN 2457-9017; Online ISSN 2392-7054 
Kyrylenko, M., (2021)

legally control and limit the functioning of subliminal advertising. In addition, recently this phenomenon in the form of pseudo-social advertising has flooded the pages of periodicals, promoting not the solution of actual social problems, but the names of the companies that sponsor the campaigns. The issue of subliminal advertising is also unexplored from the scientific perspective because most scientists who study advertising do not justify the definition of subliminal advertising, but only briefly mention the existence of such a phenomenon.

In the context of the ethics of manipulative advertising technologies, the concept of "hidden" advertising is in some cases replaced by the concept of "unfair" advertising, but this substitution is in some way incorrect because the ethical nature of the advertising message is quite adequate and what is unethical - it is the way of presenting information or choosing the means of communication for that. Subliminal advertising preponderantly does not mislead, deceive, exaggerate, does not provide inaccurate or incomplete information, it contains completely true information, but it is presented using not direct methods, but presenting a message as if unintentionally, despite the main content of the information flow, being allegedly on the periphery of the message array. It is, in the end, inconspicuous, unobtrusive, and does not impair hearing or vision. Its disadvantage is not in the ethical essence of the advertising message but in the use of subliminal means of influencing the subconsciousness and consciousness. The active functioning of subliminal advertising became possible only with the development of the latest technologies of information transmission: radio, television, cinematograph, printed media, significantly modified in the second half of the twentieth century. So, subliminal advertising is a phenomenon of the period of high technology.

Subliminal advertising can be submitted as editorial material, sponsorship, and product placement.

1. Subliminal advertising in editorial material may be expressed in the form of:

- Customized material;

- Positive or negative plot;

- Commentary;

- Information in titers;

- Advertising information in the running ticker/line.

2. Sponsorship is most often used in television. Types of sponsorship:

- Sponsorship video;

- Screensaver;

- Running ticker/line;

- Pop-up window;

- Logo or demonstration of paraphernalia;

- Interview or image plot; 
Kyrylenko, M., (2021)

- Information about the sponsor can be published by leading programs, announcers, or mentioned in the program announcement.

3. Subliminal advertising also exists in the form of product placement.

There are several types of product placement:

- visual - viewers directly see the product or logo;

- verbal - the character of the film or the commentator speaks about the goods;

- dynamic - the product (brand) is used by the characters.

Product placement can also be direct or indirect. Direct product placement is a demonstration of a product, brand, logo in the frame when they attract the attention of viewers. Indirect Product Placement involves placing the advertised object, not in the center of the screen, but the background, basically in the shade of the main material, but with it being still noticeable.

With the help of the above-described types of product placement, specific advertising tasks are solved, on which the degree of involving the product (service) in the means of communication depends.

Unlike other subliminal advertising, product placement is usually allowed in different countries around the world. It is also allowed in Ukraine. Usually, the viewer or reader is shown the advertised product or its logo, perhaps even a reminder of its good quality. With this regard, such type of advertising seems to be a very relevant topic for consideration. However, because of the product placement, the line between reality and advertising almost disappears. History of product placement knows many classic examples when the appearance of any product on movie screens made it a hit the day after the broadcast. In Ukraine, product placement is currently in the process of formation.

Concerning the problem of recognizing subliminal advertising, based on the research of S. Kolodnytska, we can identify three main features that should be taken into consideration when examining periodicals on the presence of subliminal advertising: 1) Most publications have special sections for subliminal advertising: "Thought", "View", "Company News", "Position", etc. In this way, the publishing tries, on the one hand, to present the material as an editorial one, and on the other hand - to avoid responsibility (although the law allows only two types of labeling - "advertising" and "on the rights of advertising"), so everything marked differently is inappropriate and unlawful advertising).

2) An illustration that contains an image or logo of a specific product or brand. Although such illustrations are too obvious, some customers insist that the "editorial" material with their subliminal advertising have to be illustrated with a logo.

3) Usually journalists do not sign the ordered materials with their name. They try to sign such subliminal advertisements with fictitious pseudonyms.

62 sciendo Journal of Legal Studies Volume 27 Issue 41/2021

ISSN 2457-9017; Online ISSN 2392-7054.

Web: publicatii.uvvg.ro/index.php/jls. Pages $59-71$ 
Kyrylenko, M., (2021)

"Vasile Goldiş" Western University of Arad

Subliminal Advertising: Ethical and Legal Problems of Existence in Ukraine

After analyzing various examples of subliminal advertising from movies, radio and television programs, printed materials, we can highlight some more rules on how to recognize subliminal advertising:

4) The material often mentions a specific politician or only one trademark, a third person, or a specific company (brand).

5) The material deals with a specific problem and its solution is related to a specific brand. Besides, materials may highlight the success and high achievements of enterprises in some certain spheres.

Subliminal advertising may often be present in materials that have no informational load or reason.

\subsection{The danger of subliminal advertising and the necessity for its legal regulation}

Concealed advertising is a powerful manipulative technology nowadays, which deals primarily with allusion and suggestion (reference, voice prohibition, which appeared in the biological nature of pre-humans). Subliminal advertising has a specific nature, which stems from conscious and subconscious matters and is directly related to the ethical issues of psychological influences in advertising. Subliminal advertising is absolutely everywhere: in movies, TV series, cartoons, sports. Almost every feature film advertises goods, trademarks, brands. Children are especially susceptible to such information: they instantly learn that you need to smoke a certain brand of cigarettes (because that's what your favorite character did), drink fruit beer on vacation, and so on. With the help of subliminal advertising, you can speculate on human fears (such as the ozone hole in the atmosphere, terrorism). Without realizing it, people become puppets in the hands of advertising producers. They have no choice (and this is contrary to fundamental human rights), because their subconsciousness, whether they want it or not, is influenced by subliminal advertising.

More than half of Ukrainians have a negative attitude to subliminal advertising on television, according to a poll conducted by the full-cycle media agency Nirvana Media. Notably, it was reported that $56 \%$ of Ukrainians have a negative attitude, $18 \%$ of respondents cannot answer this question and $26 \%$ are not concerned when they notice that the brand is included in a TV program, movie or series.

There are many examples of subliminal advertising in the modern mass media space, where at the subconscious level a certain desire or belief is suggested and, therefore, imposed. A suggestion is intentional and unintentional, direct and indirect. The content of indirect suggestions is available in the information flow in disguise. Such a suggestion is the subliminal advertising that is presented in the general information flow, as if not standing out. In the interpretation of subliminal advertising as a suggestion, the works of V. Bekhterev and B. Sidis became fundamental, and regarding the issue of the phenomenon of subliminal advertising as manipulation,

$S$ sciendo Journal of Legal Studies Volume 27 Issue 41/2021 
Kyrylenko, M., (2021)

Subliminal Advertising: Ethical and Legal Problems of Existence in Ukraine

the works of E. Dotsenko shall be taken into consideration. Proponents of humanistic psychology consider manipulation a violation of human rights to free expression and expression of will. Some researchers advocate a moderate stance and recognize manipulative technologies as necessary to increase the effectiveness of the impact of advertising messages on subconsciousness and consumer behavior. In subliminal advertising, depending on what the manipulator is trying to emphasize, there are several types of manipulation:

- manipulation of needs (use of desires, aspirations, interests);

- "spiritual" manipulation (formation of certain ideals and values);

- intellectual manipulation (imposition of opinions, judgments);

- manipulation of feelings (use of emotions, passions);

- symbolic manipulation (formation of a stable human reaction to certain symbols and signs).

Concealed advertising is dangerous, first of all, because it is able to exert an unconscious influence on the consumer and force him to certain actions. Such manipulations may have a damaging effect on the commercial world and humanity in its entirety depriving people of the execution of their free will and affecting fair competition in commerce.

\section{Problems and ways of improving the legal regulation of subliminal advertising in Ukraine}

\subsection{Legal regulation in the modern legislation of Ukraine}

Article 1 of the Law of Ukraine "On Advertising" defines subliminal advertising as "information about a person or product in the program, transmission, publication, if such information serves advertising purposes and may mislead individuals about the true purpose of such programs, broadcasts, publications».

Article 9 of the Law of Ukraine "On Advertising" states: "Advertising must be clearly separated from other information regardless of the forms or methods of distribution so that it can be identified as advertising. The material in which attention is drawn to a particular person or product and which forms or maintains the awareness and interest of viewers (listeners, readers) about such person or product is an advertising and is placed under the heading "advertising" or "advertising rights". Subliminal advertising is a type of advertising that, due to its negative impact on the consumer, is prohibited in Ukraine. However, it can be argued that the definition of subliminal advertising, which is proposed in the Law of Ukraine "On Advertising", does not provide for all forms of this type of advertising, which is the result of information development. That is why many types of subliminal advertising, such as "product placement", by the above definition are not subliminal advertising at all. Article 5 of the Law of Ukraine "On Advertising" states:

64 sciendo Journal of Legal Studies Volume 27 Issue 41/2021 ISSN 2457-9017; Online ISSN 2392-7054. 
Kyrylenko, M., (2021)

"Item 4. The program, the broadcast, prepared with the support of the sponsor, should be marked with titers or narration at the beginning and/or end of the program, the broadcast". In a certain way, this legalizes product placement.

In Ukraine, advertising relations are controlled by several laws: the Law of Ukraine "On Advertising", the Law of Ukraine "On Copyright and Related Rights", the Law of Ukraine "On Television and Radio Broadcasting". However, Ukrainian legislation on advertising, including hidden advertising, is very imperfect, given that the definition of "subliminal advertising" in Ukrainian law is inaccurate. First, the legislation does not contain a list of characteristics of subliminal advertising. Secondly, it is very similar to the definition of "unfair advertising". Law of Ukraine "On Advertising" provides some definitions, notably in Section 1, Article 1:

"Subliminal advertising - information about a person or product in the program, broadcast, publication, if such information serves advertising purposes and may mislead people about the true purpose of such programs, broadcasts, publications." "Unfair advertising - advertising that misleads or may mislead consumers of advertising, harm individuals, the state or society due to inaccuracies, inaccuracies, ambiguities, exaggerations, omissions, violations of the requirements of time, place and method of distribution."

There are also no clear signs of subliminal advertising and penalties for the use of hidden advertising.

The body to monitor the implementation of Ukrainian legislation on subliminal advertising is the Department of Interaction with the Verkhovna Rada of Ukraine, the Cabinet of Ministers of Ukraine on Advertising under Derzhspozhyvstandart of Ukraine, which records violations in the media and cooperates with the National Council of Ukraine on Television and Radio.

The relevant public authority has the right to:

- require advertisers, manufacturers and distributors of advertising to provide all the necessary information for the execution of the authoritative powers;

- require advertisers, manufacturers and distributors of advertising to eliminate identified violations of the legal rules;

- demand the cessation of actions that impede the exercise of state control;

- provide advertisers, manufacturers and distributors of advertising with mandatory instructions to eliminate violations;

- to make a decision on recognizing advertising as unfair, subliminal, on recognizing a comparison in advertising as illegal with a simultaneous cessation of its distribution;

- make a decision to stop the distribution of certain advertising.

The Law of Ukraine of July 11, 2003, introduced the concept of "subliminal advertising" slightly different from what it was in Law of Ukraine "On Advertising": 
Kyrylenko, M., (2021)

"Subliminal advertising is information about a person or product in a program, broadcast, publication, if such information serves advertising purposes and may mislead individuals about the true purpose of such programs, broadcasts, publications. Subliminal advertising is prohibited".

On August 20, 2015, the Verkhovna Rada registered draft law №2474a-1 "On Amendments to Certain Legislative Acts of Ukraine Concerning the Restriction of Election Campaigns and Counteraction to Hidden Advertising". In this act the Verkhovna Rada resolves: "In the Code of Ukraine on Administrative Offenses 1984, Annex to № 51, p. 1122): 1. to supplement the Code with a new Article 1564 of the following content:

"Distribution of subliminal advertising in the media, which is not identified as such in accordance with the law, in particular in the form of information, news materials - entails a fine on officials of the editorial office or television and radio."

However, the draft law was declared a subject for legislative revision.

Unfortunately, there is still no comprehensive interpretation of subliminal advertising and its classification. That is why it is very difficult to legally control and limit the functioning of subliminal advertising.

\subsection{Comparative analysis of domestic and foreign legislation on the regulation of subliminal advertising}

Recourse to foreign experience in regulating subliminal advertising at the legislative level and through self-regulation is fruitful for domestic practice, as it reveals the concept of "subliminal advertising" in the legal field of Ukraine in the context of the foreign practice of regulating subliminal advertising.

In China, the identification of advertising in the media is strictly required (Article 13 of the Law of the People's Republic of China "On Advertising"). Laws of Japan relating to advertising (Basic Law on Consumer Protection, Constitution of Consumer Rights, Code of Consumer Protection, Law "On Prevention of Inaccurate Specification", "On Trademarks", "On Prevention of Competition", "On Protection of Personal Information", "On Protection of Personal Data"), do not allow subliminal advertising. Japan is one of the leaders in the use of Product Placement in various media, but the use of Product Placement is established by law. Harsh restrictions on spam in Japan's Internet networks, which fall within the competence of state ministries, are defined by the Code of Trade Laws. Similar regulation of hidden advertising exists in South Korea and Argentina.

In the United States, there is comparatively the strictest control over surreptitious advertising as manipulation of public consciousness, here the law strictly suspends advertising if it constitutes a potential danger to consumers due to the use of manipulative technologies, despite the First Amendment to the Constitution. The complexity of the situation with the identification of advertising in the United States

66 sciendo Journal of Legal Studies Volume 27 Issue 41/2021 
is that in the national legal system there are two views on the problem: according to the first, the administrative body is empowered to determine the manipulative nature of advertising. Therefore, the recognition of an advertising message as subliminal belongs to the jurisdiction of a judicial or administrative body. The second view is based on Lenham's Law - the courts determine at their discretion what can be classified as "advertising" or "a promotion action".

The regulation of the Internet-relations is inherent in the majority of European countries as well. The use of subliminal advertising is generally prohibited in EU countries. In the UK, the tradition of legal regulation of advertising and its extensive and detailed system completely eliminates the possibility of covert methods of advertising. The legislation of the UK does not address this issue in any way. However, as the issue sometimes arises with regard to the development of information technology, the system of self-regulation in the form of the Committee on Advertising Practices (CAP), the Advertising Standards Agency (ASA), and the Broadcast Committee on Advertising Practices (BCAP) work with this matter. In German law, subliminal advertising is regulated in the context of the national Law on Unfair Competition: advertising under the guise of editorial material is considered a violation of the ethics of advertising. German self-regulatory bodies do not take part in this issue. The legislation and the system of self-regulation of subliminal advertising act uncompromisingly. The requirements for television and radio advertising in European countries are in line with the articles of the European Convention on Transfrontier Television and EU Directives 89/552/EEC on the coordination of certain provisions established by law, regulation or administration by countries-parties to the European Convention on Transfrontier Television. In particular, this applies to strict prohibitions on hidden advertising.

No law "On Advertising" of the CIS (The Commonwealth of Independent States) and the Baltic countries on subliminal advertising is perfect. The comparative analysis revealed that some of the provisions of the laws are identical. Given the number of nationally specific factors of a particular country, the laws require refinement. However, these normative acts work on and regulate the problems associated with the creativity and dissemination of subliminal advertising. In this context, the drawbacks and gaps in the domestic regulation of the problems of subliminal advertising by the Law of Ukraine "On Advertising" are clearly revealed. Art. 1 defines the concept of hidden advertising which is partly covered by the provisions of Art. 8. In accordance with Art. 9 item 5, the use of subliminal advertising is prohibited because it can cause moral damage through the use of psychological means of influence, special effects, attracting attention. According to Art. 8 item 1, it is forbidden to use the means and technologies affecting the subconsciousness. 
Kyrylenko, M., (2021)

\subsection{Suggestions for improving the legal regulation of subliminal advertising in} Ukraine

Currently, it is very difficult to legally control and limit the operation of subliminal advertising due to the fact that:

1. There is no comprehensive interpretation of subliminal advertising and its classification.

2. There are no clear signs for the determination of subliminal advertising and penalties for the use of hidden advertising.

3. The definition of "subliminal advertising" in Ukrainian legislation is inaccurate, as it does not contain a list of distinguishing characteristics of subliminal advertising, and is very similar to the definition of "unfair advertising".

Analysis of the ethical aspect of subliminal advertising, determination of the need for its legal restriction, examination of the Law of Ukraine "On Advertising", as well as comparison of legal regulation of subliminal advertising in Ukraine and developed countries allowed to develop suggestions and ways to improve legal regulation of subliminal advertising in Ukraine:

1. The definition of surreptitious advertising in national law and the system of penalties for its use must be clearly defined.

2. In order to be able to clearly identify the existence of subliminal advertising and to distinguish subliminal and unethical, unfair and inappropriate advertising, it is necessary to develop features and a uniform classification of subliminal advertising.

3. It is necessary to clearly prescribe the types of punishment for hidden advertising, unethical, unfair and inappropriate advertising.

4. Involving scientists and practitioners in the development of a clear definition of subliminal advertising, its features and the system of penalties for the use of subliminal advertising is a beneficial option.

5. The Antimonopoly Committee of Ukraine shall also be involved in the process of regulation of subliminal advertising.

The activity of detecting and stopping violations in the advertising market is entrusted by law to specially authorized state bodies, including the Antimonopoly Committee of Ukraine, which monitors compliance with advertising legislation within its powers to monitor compliance with legislation on protection against unfair competition.

Now the Antimonopoly Committee of Ukraine regulates comparative and misleading advertising. According to Article 7 of the Law of Ukraine "On the Antimonopoly Committee of Ukraine", its powers include:

- Consideration of the cases of administrative offenses, adopting resolutions and checking their legality and validity;

68 sciendo Journal of Legal Studies Volume 27 Issue 41/2021 
Kyrylenko, M., (2021)

"Vasile Goldiş" Western University of Arad

Subliminal Advertising: Ethical and Legal Problems of Existence in Ukraine

- Inspection of business entities, associations, authorities, local governments, administrative and economic governing bodies and the execution of control over their activities in compliance with the requirements of the legislation on protection of economic competition;

- Considering applications and cases of violation of the legislation on protection of economic competition, conducting inspections and, in other cases provided by law, require relevant and sufficient information in the field, including the one with limited access;

- Provision of the legal expertise and appointment of an expert from among the individuals who have the necessary knowledge to provide an expert opinion with regard to subliminal advertising.

\section{Conclusions}

Subliminal advertising is commercially, socially or politically important information for the initiator of communication, which is perceived by the audience as objective. Hidden advertising is dangerous, first of all, because it is able to exert an unconscious influence on the consumer and force him to take certain actions. It affects the human subconscious and manipulates their behavior, and thus harms not only consumers of advertising, as it misleads, disorients, has a covert effect, but also harms media outlets that do not receive adequate payment for advertising, and by ignoring the laws, the requirements of journalistic ethics demoralize.

In Ukraine, advertising relations are regulated by several laws: the Law of Ukraine "On Advertising", the Law of Ukraine "On Copyright and Related Rights", the Law of Ukraine "On Television and Radio Broadcasting". However, the legislation of Ukraine on advertising, in particular subliminal one, is very imperfect, as there are no clear criteria for the determination of subliminal advertising and penalties for it. That is why it needs improvement and refinement.

Taking everything mentioned above into consideration, we can conclude that there are many ethical and legal issues regarding subliminal advertising that require legal regulation:

1. The definition of subliminal advertising in national law and the system of penalties for its use must be clearly defined.

2. In order to be able to clearly identify the existence of subliminal advertising, and to be able to distinguish subliminal advertising from unethical, unscrupulous and inappropriate advertising, it is necessary to develop characteristics and a uniform classification of subliminal advertising.

3. It is necessary to clearly prescribe the types of punishment for hidden advertising, unethical, unfair and inappropriate advertising.

4. It is appropriate to involve scientists and practitioners in the development of a clear definition of subliminal advertising, its features and the system of penalties. 
Kyrylenko, M., (2021)

5. The Antimonopoly Committee of Ukraine shall be involved in the regulation of subliminal advertising.

Creating a comprehensive system of legal regulation of subliminal advertising will strengthen the stability of society and protect human and commercial rights in the modern world.

\section{Acknowledgments}

The author thanks the anonymous reviewers and editor for their valuable contribution.

\section{Funding}

This research received no specific grant from any funding agency in the public, commercial, or not - for - profit sectors.

\section{Author Contributions}

The entire article was written by Kyrylenko Mariia.

\section{Disclosure Statement}

The author has not any competing financial, professional, or personal interests from other parties.

\section{References}

1. Bekhterev, V.M. (1908). Inculcation and its role in public life [Electronic resource]. Saint-Petersburg: Edition of K.L. Ricker, 1908. - Access mode: http://www.psylib.ukrweb. net/books/behtv01/index.htm.

2. Directives of the European Union № 89/552 // EWG, 97/7 / EG, 2001/31 / EG, 2002/58 / EG, 2003/33 / EG [Electronic resource]. - Access mode: http://www. zakon.rada.gov.ua.

3. Dotsenko, E.L. (2003). Psychology of manipulation: phenomena, mechanisms and protection - [3rd ed.]. Moscow, pp. 304.

4. European Convention on Transfrontier Television (ukr/rus) (ETS № 132) Council of Europe; Convention, International document of 05.05.1989 № ETS (132) [Electronic resource]. - Access mode: http://zakon2.rada.gov.ua/laws/show/994_444.

5. Hrytsyuta, N.M. (2011). Cross-border system of self-regulation of advertising in the EU - an effective means of supporting ethical standards of the industry. Current issues of mass communication.

6. Hrytsyuta, N.M. (2011). Practice of development and establishment of ethical principles and professional standards of advertising in France. Scientific notes of the Institute of Journalism of KNU, Vol. 44.

7. Hrytsyuta, N.M. (2012). The experience of advertising regulation in Germany: the impact on the ethics of advertising communication. Scientific notes of the Institute of Journalism of KNU, Vol. 49, pp. 107-114.

70 sciendo Journal of Legal Studies Volume 27 Issue 41/202 ISSN 2457-9017; Online ISSN 2392-7054. 
Kyrylenko, M., (2021)

Subliminal Advertising: Ethical and Legal Problems of Existence in Ukraine

8. Industrial Television Committee, (2005). Self-regulation of advertising in Europe: an analysis of the system of self-regulation of advertising and the code of advertising practice in Europe. - [4 ed.], pp. 169.

9. Kolodnytska, S.A. How to recognize subliminal advertising in the newspapers [Electronic resource] URL: http://osvita.mediasapiens.ua/ material/1954.

10. Law of the People's Republic of China On the Protection of the Rights and Interests of Consumers [Electronic resource]. http://www.lawinfochina.com/display.asp? $\mathrm{Db}=1 \& \mathrm{id}=445 \&$ keyword.

11. Law of Ukraine "On Advertising" [Electronic resource]. - Access mode: https: //zakon.rada.gov.ua/rada/show/270/96.

12. Law of Ukraine "On Copyright and Related Rights" [Electronic resource]. - Access mode: https://zakon.rada.gov.ua/laws/show/3792-12/stru2.

13. Law of Ukraine "On Television and Radio Broadcasting" [Electronic resource]. - Access mode: https://zakon.rada.gov.ua/laws/show/3759-12/ed20171013.

14. Malchenko, N.V. (2012), Viktor Zherebnyuk's social initiatives are aimed at raising the level of development of the agricultural complex. Litynsky Visnyk, no. 46.

15. Malchenko, N.V. (2012). Agrarians of Lityn region - the first in the area. Lityn Herald, no. 48 .

16. Musykant, V.L. (2001). Advertising and PR-technologies, pp. 577.

17. Musykant, V.L. (2002). Formation of the brand by means of PR and advertising, Economist, pp. 286.

18. Petrik, V.K. (2012). Delicious, no. 43.

19. Sidis, B.O. (1902). Psychology of suggestion. B. Sidis; [trans. from English -M.

Kolokolova]. Saint-Petersburg: Ed. by B.N. Zvonareva, pp. 376. 